\title{
Satisfying the population's demand for neighbourhood improvement: transdisciplinary approach of programme solutions
}

\author{
Tatiana Barsukova ${ }^{1}$, Larisa Parsieva ${ }^{2}$, Larisa Gatsalova $^{2}$, Lyudmila Latysheva ${ }^{3}$, and \\ Valentine Ivashova ${ }^{3,}$ \\ ${ }^{1}$ North Caucasus Federal University, 1, Pushkin Str., Stavropol, 355017, Russia \\ ${ }^{2}$ North Ossetian State University, 44-46, Vatutina Str., Vladikavkaz, 362025, Russia \\ ${ }^{3}$ Stavropol State Agrarian University, 12, Zootechnicheskiy lane, Stavropol, 355017, Russia
}

\begin{abstract}
The article provides a theoretical review of the literature on assessing the relevance of various aspects of community improvement. The authors have developed a toolkit for analyzing the population's demand and level of satisfaction, including 15 indicators. Empirical data on the requests for the improvement of settlements have been collected on the territory of the South of Russia by electronic questionnaires 819 people, permanent residents of 18 settlements by random stratified sampling. Statistical analysis using the method of allocation of principal components in the program SPSS Statistics (version 21) allowed to develop models of the population's demands on improving settlements of the Stavropol Territory. The applied modelling algorithm allows improving the decision-making system in the field of improvement of territories with the involvement of stakeholders' opinions. Shows the possibilities of developing a transdisciplinary approach for quality improvement of people's lives and sustainable development of territories.
\end{abstract}

\section{Introduction}

Public amenities in settlements must satisfy the population's demand for comfortable living and material and spiritual benefits. For modern people, this is an essential prerequisite for the choice of place of residence and, therefore, the demographic well-being of the area, without which economic growth is also impossible. Therefore, the municipality authorities take care to saturate public spaces with modern comfort attributes and ensure the consumer demand of the population for retail outlets, areas for recreation, sports, cultural and leisure activities, catering, etc.

The factors of the comfort of living in settlements are the subject of study in socioeconomic, demographic and humanitarian studies of scientists worldwide. Let us consider the relevant aspects of these studies, which are essential in forming the population's demand

\footnotetext{
*Corresponding author: vivashov@mail.ru
} 
for comfortable living and consumption of material and spiritual benefits and will allow constructing key models of such demand.

The research authors Syrbe R.-U., Neumann I., Grunewald K., Brabec J., Bastian O. note that the population's quality of life depends on urban living space [1]. Based on a comparative analysis of research results in two European countries, the article shows the importance of leisure opportunities for the population in the urban environment. Furthermore, the authors note residents' statements that urban nature positively affects people's physical and psychological well-being [2]. Thus, the population's demand for ecosystem services is articulated: the availability of park areas in the city with opportunities for cultural and leisure activities.

An essential component of modern man's life activity is to meet the demand for cultural services. The author of the article Bertacchini E., Venturini A., Zotti R., emphasises its heterogeneity and the need to focus on the cultural traditions of the people living in the territory of municipalities [3]. The possibility to reproduce people's cultural capital gives stability and well-being to the territory. Thus, the diversity of cultural space and the possibility of choosing a cultural trajectory play an essential role in modelling the population's request for the improvement of the territory. In turn, implementing such a request ensures the comprehensive development of the individual and the population's involvement in positive social practices and the preservation of the natural and culturalhistorical heritage of the territory [4].

The author Nordbakke S.T.D. [5] raises an urgent issue of the improvement of territories of settlements in his article. It is about the positive impact of activity outside the home and mobility of people in old age. For our study, there is a critical approach focusing on the different demands of citizens in the improvement of public spaces of settlements $[6,7]$. These are the demands of young people, families with children of school and preschool age, people of the older generation. In addition, it is essential to segment the requests concerning the consumer model of behaviour depending on the target life attitudes of an individual $[8,9,10]$.

The alignment of living conditions in settlements of different types and sizes serves as an essential factor in preserving the population and solving the demographic aspects of territorial development. The author of the publication Ivolga, A. proposes a system for assessing the economic potential of rural areas that includes indicators: natural conditions and resources; labour resources; living conditions in rural areas; demographic situation; social-cultural and leisure infrastructure; access of rural residents to modern services of communication, transport, education, medicine, consumer services and other benefits, familiar to urban residents [12]. We see significant aspects for developing approaches to modelling the population's demand for the improvement of territories: the levelling of the level of improvement and the consistency of such assessment. This approach is articulated in several studies $[13,14,15]$.

Thus, the conducted review and analysis of the research results show the relevance of modelling the population's demand in the improvement of territories and the demand for a transdisciplinary approach to its consideration. Furthermore, clarification of the parameters of the demand itself and the level of its satisfaction with the involvement of the opinions of a wide range of stakeholders $[16,17,18]$ provides the most accurate and relevant information for making policy decisions of territorial development [19, 20, 21].

\section{Materials and methods}

The methods used to study the satisfaction of the population's demand for landscaping were as follows: 
- analysis of scientific literature in the subject area of the research, which provided an understanding of the level of relevance of the raised topic and modern approaches to the consideration of the problem and clarification of the conceptual apparatus of the research;

- a random stratified electronic questionnaire survey of 819 permanent residents in 18 localities, using a 15 -indicator instrument;

- statistical analysis of the survey data using the extraction of the principal components in SPSS Statistics (version 21);

- modelling of the population's demand for amenities in the settlements of the Stavropol Territory.

The applied modelling algorithm helps to improve the decision-making system in the field of territory improvement by involving the stakeholders' opinions. The transdisciplinary approach in the development of programmatic solutions for the area improvement is updated through the population's involvement in designing the survey tools.

\section{Results and discussion}

The total explained variance for survey participants from urban and rural areas of the Stavropol Territory, who rated their satisfaction with their request for landscaping, is $68.1 \%$ and is defined by four components. Table 1 presents the data.

Table 1. Total explained variance of estimates of satisfaction of the population's request for improvement of residential areas.

\begin{tabular}{|c|c|c|c|c|c|c|c|c|c|}
\hline \multirow[b]{2}{*}{ نे } & \multicolumn{3}{|c|}{ Initial eigenvalues } & \multicolumn{3}{|c|}{$\begin{array}{c}\text { Sums of extraction load } \\
\text { squares }\end{array}$} & \multicolumn{3}{|c|}{$\begin{array}{c}\text { Sums of rotation load } \\
\text { squares }\end{array}$} \\
\hline & 苞 & 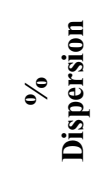 & 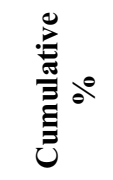 & $\stackrel{5}{0}$ & 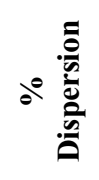 & 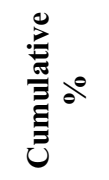 & 要 & 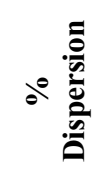 & 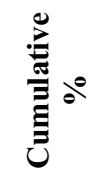 \\
\hline 1 & 5.853 & 39.021 & 39.021 & 5.853 & 39.021 & 39.021 & 4.182 & 27.879 & 27.879 \\
\hline 2 & 1.883 & 12.556 & 51.577 & 1.883 & 12.556 & 51.577 & 2.881 & 19.204 & 47.083 \\
\hline 3 & 1.430 & 9.535 & 61.112 & 1.430 & 9.535 & 61.112 & 1.694 & 11.294 & 58.377 \\
\hline 4 & 1.055 & 7.031 & 68.143 & 1.055 & 7.031 & 68.143 & 1.465 & 9.766 & 68.143 \\
\hline 5 & 0.748 & 4.989 & 73.132 & & & & & & \\
\hline 6 & 0.722 & 4.815 & 77.947 & & & & & & \\
\hline 7 & 0.658 & 4.384 & 82.332 & & & & & & \\
\hline 8 & 0.562 & 3.746 & 86.078 & & & & & & \\
\hline 9 & 0.485 & 3.231 & 89.308 & & & & & & \\
\hline 10 & 0.434 & 2.892 & 92.201 & & & & & & \\
\hline 11 & 0.321 & 2.141 & 94.341 & & & & & & \\
\hline 12 & 0.304 & 2.024 & 96.365 & & & & & & \\
\hline 13 & 0.238 & 1.588 & 97.952 & & & & & & \\
\hline 14 & 0.197 & 1.314 & 99.266 & & & & & & \\
\hline 15 & 0.110 & 0.734 & 100.000 & & & & & & \\
\hline
\end{tabular}

The listed 15 characteristics of satisfaction of the population's request in the improvement of territories of the settlements, the significance of which was assessed in the course of a sample survey of residents of the Stavropol Territory, were grouped into four 
factors in the factor analysis performed by the Rotation Method: Varimax with Kaiser Normalization (Rotation converted in 7 iterations). The generalised opinion of the inhabitants of settlements, who have specific requirements for improving the area to achieve the expected quality of life, is of interest. This opinion of residents should be taken into account in the design of the socio-economic development of settlements.

Table 2. Matrix of the rotated components of the factors of satisfaction of the population's demand for improvement of residential areas.

\begin{tabular}{|l|c|c|c|c|}
\hline & \multicolumn{4}{|c|}{ Component } \\
\hline & $\mathbf{1}$ & $\mathbf{2}$ & $\mathbf{3}$ & $\mathbf{4}$ \\
\hline $\begin{array}{l}\text { 1. Schedule of cultural and leisure } \\
\text { facilities that are convenient for } \\
\text { visitors }\end{array}$ & -0.126 & 0.057 & -0.100 & $\mathbf{0 . 8 4 5}$ \\
\hline $\begin{array}{l}\text { 2. Events are held at convenient times } \\
\text { for visitors }\end{array}$ & 0.252 & 0.074 & 0.115 & $\mathbf{0 . 7 7 6}$ \\
\hline $\begin{array}{l}\text { 3. Availability of sales points with } \\
\text { printed, souvenir products }\end{array}$ & $\mathbf{0 . 7 1 2}$ & 0.478 & -0.122 & 0.004 \\
\hline $\begin{array}{l}\text { 4. Availability of restaurant, cafe, } \\
\text { buffet in public areas }\end{array}$ & 0.583 & $\mathbf{0 . 6 0 3}$ & -0.183 & 0.064 \\
\hline 5. Children's playroom in the mall & $\mathbf{0 . 8 1 3}$ & 0.263 & -0.037 & 0.054 \\
\hline $\begin{array}{l}\text { 6. Children's playgrounds with rides, } \\
\text { swings in neighbourhoods of the } \\
\text { settlement }\end{array}$ & $\mathbf{0 . 7 8 5}$ & 0.088 & 0.156 & 0.243 \\
\hline 7. Outdoor sports field & $\mathbf{0 . 7 9 6}$ & -0.050 & 0.274 & -0.115 \\
\hline $\begin{array}{l}\text { 8. Park with rides and recreation } \\
\text { areas }\end{array}$ & $\mathbf{0 . 7 3 0}$ & 0.374 & 0.024 & 0.051 \\
\hline 9. Quality of internet access, Wi-Fi & $\mathbf{0 . 7 6 8}$ & 0.263 & 0.068 & -0.002 \\
\hline $\begin{array}{l}\text { 10. Concert venues, cultural and } \\
\text { recreational organisations, public } \\
\text { performances }\end{array}$ & 0.141 & 0.113 & $\mathbf{0 . 7 9 3}$ & 0.080 \\
\hline $\begin{array}{l}\text { 11. Additional education: circles, } \\
\text { sections, excursions }\end{array}$ & -0.040 & 0.350 & $\mathbf{0 . 7 8 3}$ & -0.084 \\
\hline 12. Shopping centres, shops & 0.333 & $\mathbf{0 . 5 9 7}$ & 0.158 & 0.059 \\
\hline 13. Pay parking lots & 0.092 & $\mathbf{0 . 6 8 9}$ & 0.265 & 0.221 \\
\hline 14. Gyms & 0.228 & $\mathbf{0 . 7 2 8}$ & 0.102 & 0.003 \\
\hline 15. Public play facilities for children & 0.167 & $\mathbf{0 . 7 0 4}$ & 0.411 & -0.047 \\
\hline
\end{tabular}

The listed 15 characteristics of satisfaction of the population's demand for the improvement of the territories of the settlements, the significance of which was assessed in the course of a sample survey of the Stavropol Territory residents, were grouped into four models as a result of the factor analysis performed by the Rotation Method: Varimax with Kaiser Normalization (Rotation converted in 7 iterations).

According to the contents of the grouped characteristics of the population's satisfaction with the request for improvement of the territories of the settlements, we can say that a set of variables determines the first model: children's playroom in a shopping centre (factor load $\mathbf{0 . 8 1 3}$ ); outdoor sports ground (factor load 0. 796); playgrounds with rides, swings in the residential areas (factor load factor $\mathbf{0 . 7 8 5}$ ); quality of Internet access, Wi-Fi (factor load factor $\mathbf{0 . 7 6 8}$ ); park with rides and recreation areas (factor load factor $\mathbf{0 . 7 3 0}$ ); availability of retail outlets with printed, souvenir products (factor load factor $\mathbf{0 . 7 1 2}$ ). Thus, the first 
enquiry model can be interpreted as providing a set of health and leisure spaces in a settlement, prioritising visitors with pre-school and school-age children.

A set of variables determines the second model: Gyms (0.728); Children's play complexes in open access $(\mathbf{0 . 7 0 4})$; paid car parks $(\mathbf{0 . 6 8 9})$; availability of restaurant, café, buffet in public areas $(\mathbf{0 . 6 0 3})$; shopping centres, shops $(\mathbf{0 . 5 9 7})$. Thus, the second demand model can be interpreted as a settlement space with the structural characteristics of satisfying mainly functional needs: buying food and things, consuming restaurant services, playing sports to maintain health.

A set of variables determines the third model: concert venues, cultural and leisure organisations, mass performances $(\mathbf{0 . 7 9 3 )}$, additional education: circles, sections, excursions $(\mathbf{0 . 7 8 3})$. Thus, the third demand model can be interpreted as the spaces of a settlement to satisfy cultural and leisure consumer preferences.

A set of variables determines the fourth model: schedule of cultural and leisure organisations convenient for visitors $(\mathbf{0 . 8 4 5})$; events are held conveniently for visitors (0.776). Thus, the fourth demand model can be interpreted as the preferential orientation of all public spaces in settlements (shopping and leisure, sports and recreational, cultural and leisure, restaurant, etc.) to a schedule and mode of operation convenient for the population.

\section{Conclusion}

The theoretical analysis of the population's actual requests for the improvement of public spaces of settlements of various types, the empirical results of the study conducted in the territory of southern Russia allow us to draw some conclusions on the problem under study.

The review and analysis of the research results show the relevance of modelling the population's demand in the improvement of territories and the demand for a transdisciplinary approach to its consideration. Clarification of the parameters of the demand itself and the level of its satisfaction with the involvement of a wide range of stakeholders provides the most accurate and relevant information for making policy decisions of territorial development.

Characteristics of satisfaction of the population's demand for the improvement of the territories of the settlements, the significance of which was assessed in the course of a sample survey of the residents of the Stavropol Territory, as a result of the factor analysis carried out by Rotation Method: Varimax with Kaiser Normalization (Rotation converted in 7 iterations) were grouped into four models.

1. The first model of the population's demand for improvement of the territory providing a complex of health and entertainment spaces of the settlement with the priority of visitors with children of preschool and school-age.

2. The second model of the population's demand for the territory's improvement is the organization of the settlement's space with the structural characteristics of meeting mainly functional needs: buying food and things, consuming restaurant services, doing sports to maintain health.

3. The third model of the population's demand for the improvement of the territory is the organization of the settlement space for the satisfaction of the cultural and leisure consumer preferences.

4. The fourth model of the population's demand for territory improvement can be interpreted as the preferential orientation of all public spaces of the settlements (shopping and entertainment, sports and recreational, cultural and leisure, restaurant, etc.) to the schedule and mode of operation convenient for the population. 


\section{Acknowledgments}

The research was conducted within the framework of the state assignment of the FSBEI HE "North Ossetian State University named after Kosta Levanovich Khetagurov" on the theme "The North Caucasus in the historical and cultural processes of the XX-XXI centuries".

\section{References}

1. R.-U. Syrbe, I. Neumann, K. Grunewald et al., Land 10(4), 341 (2021)

2. A. Federici, Journal of Physical Education and Sport 21(56), 520-525 (2021)

3. E. Bertacchini, A. Venturini, R. Zotti, Journal of Cultural Economics (2021)

4. I.A. Arsenenko, L.M. Donchenko, I.A. Donetc et al., International Multidisciplinary Scientific GeoConference Surveying Geology and Mining Ecology Management, SGEM 5.2, 709-716 (2020)

5. S.T.D. Nordbakke, International Journal of Environmental Research and Public Health 16(24), 5109 (2019)

6. A. Pancewicz, IOP Conference Series: Materials Science and Engineering 603(3), 032061 (2019)

7. J. Surjani, R. Hiremath, K. Rajagopal, International Journal of Innovative Technology and Exploring Engineering 8(11), 335-339 (2019)

8. I.A. Shchetkina, IOP Conference Series: Earth and Environmental Science 274(1), 012146 (2019)

9. T.A. Kokhan, E.V. Zhirnova, N.S. Lazutina, et al., Journal of Environmental Management and Tourism 10(2), 360-365 (2019)

10. H. Choi, Advances in Intelligent Systems and Computing 483, 615-624 (2017)

11. K. Shahnazipour, K. Javanmardi, IIOAB Journal 7, 278-286 (2016)

12. A. Ivolga, Global Perspectives on Trade Integration and Economies in Transition, 262280 (2016)

13. R. Sassatelli, Modern Italy 20(3), 237-249 (2015)

14. M.K. Gorshkov, Sotsiologicheskie Issledovaniya 1, 35-44 (2015)

15. K.M. Leyden, A. Goldberg, P. Michelbach, Urban Affairs Review 47(6), 861-888 (2011)

16. F. Farhadi, SHUSER 2011 - 2011 International Symposium on Humanities, Science and Engineering Research 6008498, 4-7 (2011)

17. F. Azaiza, A. Rimmerman, T. Croitoru, D. Naon, International Journal of Social Welfare, 20(1), 97-103 (2011)

18. K. Drenkhahn, Monatsschrift fur Kriminologie und Strafrechtsreform 93(4), 258-272 (2010)

19. M. Silverstein, M.G. Parker, Research on Aging 24(5), 528-547 (2002)

20. J. Boelhouwer, Social Indicators Research 58(1-3), 115-140 (2002)

21. M. Perez Samper, Cuadernos de historia moderna 26, 11-55 (2001) 